THIS ARTICLE IS FORTHCOMING IN INTERNATIONAL JOURNAL OF REFUGEE LAW (2010) ISSUE 22 NUMBER 2.

\title{
The Changing Character of Armed Conflict and the Implications for Refugee Protection Jurisprudence
}

\author{
Hélène Lambert and Theo Farrell ${ }^{1}$
}

\section{INTRODUCTION}

EC Directive 2004/83 on minimum standards for the qualification and status of third country nationals or stateless persons as refugees or as persons who otherwise need international protection and the content of the protection granted ${ }^{2}-$ hereinafter the Qualification Directive combines two forms of international protection: traditional or classical refugee protection under the 1951 Convention Relating to the Status of Refugees ${ }^{3}$ (namely, refugee status), and subsidiary protection under human rights law (namely, subsidiary protection status) - the content of which had remained until then at the discretion of the Member States. The Qualification Directive was created as 'the heart of the Common European Asylum System'; it is one of the most important pieces of European legislation introduced in the area of asylum because it expands the scope of states' obligation towards refugees under international refugee law to include other persons in need of international protection under international human rights law. ${ }^{5}$

This article focuses on a key aspect of the Qualification Directive, namely the grounds of eligibility for subsidiary protection. These grounds rest on a test for 'serious harm' which would be present if the applicant were returned to his or her country of origin. If a genuine risk of such harm is found, the applicant would qualify for protection. Article 15 of the Directive defines the 'serious harm' in terms of (a) death penalty, (b) torture or degrading treatment, and (c) 'serious and individual threat' to a person arising from a situation of armed conflict. In this article, we examine how English (to mean England and Wales) judicial authorities have applied the third paragraph (i.e., Article 15(c) of the Qualification Directive) in recent asylum cases. In such cases, English and French judicial authorities have had to assess (1) the severity of armed conflict and (2) measuring individual risk to asylum seekers. We argue that such assessments

\footnotetext{
${ }^{1}$ Dr. Hélène Lambert, Reader in Law, University of Westminster, and Professor Theo Farrell, Department of War Studies, King's College London. We wish to thank most sincerely Roger Errera and Mark Symes for providing us with material not easily accessible to the public. We also thank Martin Bayly for his research assistance. Professor Farrell's work was funded by an ESRC/AHRC Fellowship (RES-071-027-0069) awarded under the Research Council's Global Uncertainities Programme.

${ }^{2}$ Council Directive 2004/83/EC of 29 April 2004, Official Journal L 304, 30/09/2004 p.0012 - 0023.

${ }^{3}$ Convention Relating to the Status of Refugees, signed in Geneva on 28 July 1951. 189 U.N.T.S. 150, entered into force 22 April 1954.

${ }^{4}$ European Commission, Proposal for a Council Directive on minimum standards for the qualification and status of third country nationals and stateless persons as refugees or as persons who otherwise need international protection, COM (2001) 510 final, p.2. The Qualification Directive has its legal basis in Article 63(1)(c) of the EC Treaty.

${ }^{5}$ Hélène Lambert, 'The EU Asylum Qualification Directive, Its Impact on the Jurisprudence of the United Kingdom and International Law', International and Comparative Law Quarterly 55 (2006), 161-192; Jane McAdam, 'The European Union Qualification Directive: The Creation of a Subsidiary Protection Regime', International Journal of Refugee Law 17 (2005), 461-516.
} 
must be informed by an understanding of the changing character of armed conflict, which has increased the threat to civilians in conflict, and by the human security paradigm, which offers a new way of conceptualising the threats to individuals in and from conflict.

It is generally recognised that the Qualification Directive draws on the Member States systems and best practices on subsidiary protection which themselves reflect the jurisprudence of the European Court of Human Rights and general principles of international humanitarian law. ${ }^{6}$ Regarding Article 15, a distinction can be drawn between Article 15(a) and (b) which draw on prescribed standards, and Article 15(c) which draws mainly on state practice, ${ }^{7}$ 'except insofar as it has regard to the right to life enshrined in ECHR [European Convention on Human Rights] article 2'. ${ }^{8}$ Prior to the adoption of the Qualification Directive, the practice of most EU states was not to return unsuccessful asylum seekers at risk of serious human rights violations and/or who had fled civil war or generalised violence. ${ }^{9}$ In $H H$ (Iraq) for instance, the Court of Appeal (for England and Wales) referred to a 'departmental operational enforcement manual' which for many years and until 14 January 2008 (date when it was withdrawn) stated: 'Enforcement action should not be taken against Nationals who originate from countries which are currently active war zones'. ${ }^{10}$ Even though such policy was never made public (to avoid attracting too many nationals from countries at war or countries where 'uncontrolled violence is endemic'), Article 15(c) elevated this practice to a minimum standard with the effect that 'the practice of the UK and many other European states in this regard has in large part acquired the force of law'. ${ }^{11}$ In France, protection in the form of territorial asylum (asile territorial) was recognised to persons whose life was threatened or who were at risk of treatment contrary to Article 3 ECHR. ${ }^{12}$ This form of protection was therefore most relevant to Algerian nationals fleeing the civil war and to whom Article 1A(2) of the Refugee Convention did not apply because civil war, as a ground of refugee protection, was not then recognised. This Government' practice of granting territorial asylum to person fleeing a civil war or treatment contrary to Article 3 ECHR was replaced by the concept of subsidiary protection following the transposition of the provisions of the Qualification Directive in the Act of 10 December 2003, incorporated into the Immigration and Asylum Code (Code de l'entrée et du séjour des étrangers et du droit d'asile or Ceseda, 2003).

\footnotetext{
${ }^{6}$ Commentary on Article 15, COM (2001) 510 final, pp.5-6. See also Opinion of the Committee of the Regions of 16 May 2002 on the Commission proposal (O.J. C/2002/278/44). Note that this reference aside, neither the original proposal nor the final text of the Qualification Directive refer to international humanitarian law; yet the latter clearly refers to international refugee law and international human rights law as a legal framework.

${ }^{7}$ Qualification Directive (EC Directive 2004/83), Preamble, Recital (25).

${ }^{8}$ Court of Appeal in $Q D \& A H$ (Iraq) v Secretary of State for the Home Department [2009] EWCA Civ 620 (24 June 2009), para.21.

${ }^{9}$ UNHCR, Submissions, Annexure 1: State Practice in 1999, in the Court of Appeal C5/2008/1706 on Appeal from the IAT, $Q D \& A H$ (Iraq) $v$ Secretary of State Secretary of State for the Home Department [2009] EWCA Civ 620 (24 June 2009).

${ }^{10}$ Secretary of State for the Home Department v HH (Iraq) [2009[ EWCA Civ 727.

${ }^{11} \mathrm{HH}$ (Iraq), para.6.

${ }^{12}$ UNHCR, Submission, Annexure 1, $Q D$ and $A H$ (Iraq). In addition, the Aliens Act pf 11 May 1998 provided for constitutional asylum but its relevance has remained very limited in practice. See Hélène Lambert, Francesco Messineo, and Paul Tiedemann, 'Comparative Perspectives of Constitutional Asylum in France, Italy, and Germany: Requiescat in Pace?', Refugee Survey Quarterly 27 (2008), pp.16-32.
} 
The complexity (and resulting ambiguity) of the drafting history of Article 15 is well-commented in McAdam's Complementary Protection in International Refugee Law and so will not be discussed here. ${ }^{13}$ Suffice to say that between 2001 and 2004, Article 15 (and paragraph (c) in particular) was the subject of much discussion and re-drafting in the Council. The final text 'is said to reflect existing practice in Member States ... The result is a political compromise'. ${ }^{14}$ In the end, it is a blend between Member States' obligations under the Temporary Protection Directive, the Council of Europe Committee of Ministers' Recommendation (2001) 18 on subsidiary protection of 27 November 2001, and 'EU Member States' repeated support for UNHCR's mandate activities for victims of indiscriminate violence (linked to other regional agreements such as the OAU Convention and the Cartagena Declaration)'. ${ }^{15}$

The final text of the Qualification Directive was adopted by the Council on 29 April 2004. The text of the provisions in the Directive most relevant to the issue of armed conflict follows. Note that the Commission of the European Communities recently considered an amendment of Article 15(c) to be unnecessary in view of the interpretative guidance provided by the European Court of Justice (ECJ) in the case Elgafaji (Justice and Home Affairs) C-465/07 (17 February 2009) 'and of the fact that the relevant provisions were found to be compatible with the ECHR' ${ }^{16}$ Hence, the current discussion on a proposal aiming at remedying the deficiencies identified in the Qualification Directive and at addressing the concerns expressed by the member states, ${ }^{17}$ has no effect on Article 15(c).

Article 2(e) of the Qualification Directive provides:

(e) 'person eligible for subsidiary protection' means a third country national or a stateless person who does not qualify as a refugee but in respect of whom substantial grounds have been shown for believing that the person concerned, if returned to his or her country of origin, or in the case of a stateless person, to his or her country of former habitual residence, would face a real risk of suffering serious harm as defined in Article 15, and to whom Article 17(1) and (2) do not apply (exclusion clauses), and is unable, or, owing to such risk, unwilling to avail himself or herself of the protection of that country. (our emphasis)

According to Article 15

Serious harm consists of:

\footnotetext{
13 Jane McAdam, Complementary Protection in International Refugee Law, Oxford University Press, 2007.

${ }^{14}$ McAdam, Complementary Protection, p.64.

${ }^{15}$ McAdam, Complementary Protection, p.71.

${ }^{16}$ Commission Proposal for a Directive of the European Parliament and of the Council on minimum standards for the qualification and status of third country nationals or stateless persons as beneficiaries of international protection and the content of the protection granted, COM (2009) 551 final, Brussels 21.10.2009, p.6.

${ }^{17}$ Commission Staff Working Document accompanying the Proposal for a Directive of the European Parliament and of the Council on minimum standards for the qualification and status of third country nationals or stateless persons as beneficiaries of international protection and the content of the protection granted - Impact Assessment, SEC (2009) 1373 final, Brussels 21.10.2009.
} 
(a) death penalty or execution; or

(b) torture or inhuman or degrading treatment or punishment of an applicant in the country of origin; or

(c) serious and individual threat to a civilian's life or person by reason of indiscriminate violence in situations of international or internal armed conflict. (our emphasis)

In addition, recital (26) in the Preamble to the Directive provides that

Risks to which a population of a country or a section of the population is generally exposed do normally not create in themselves an individual threat which would qualify as serious harm. (our emphasis)

And recital (10) provides: ${ }^{18}$

This Directive respects for fundamental rights and observes the principles recognized in particular by the Charter of Fundamental Rights of the European Union. In particular this Directive seeks to ensure full respect for human dignity and the right to asylum of applicants for asylum and their accompanying family members. (our emphasis)

The Qualification Directive considers the 1951 Refugee Convention and 1967 Protocol as the 'cornerstone of the international legal regime for the protection of refugees'. ${ }^{19}$ It further refers to the EU Charter of Fundamental Rights ${ }^{20}$ and to 'international obligations under human rights instruments and practices existing in the Member States'. ${ }^{21}$ As far as treatment of persons covered by the Directive is concerned, other instruments of international law are relevant too. ${ }^{22}$

Key elements of Article 15(c) have been examined on numerous occasions by the domestic courts (including the French Conseil d'Etat and the Court of Appeal for England and Wales) and once so far by the European Court of Justice (ECJ).

3. THE APPROACH OF THE ENGLISH AND FRENCH COURTS TO THE INTERPRETATION OF ARTICLE $15(c)$

In this section, we shall discuss the interpretation given by the English and French courts to the key elements of Article 15(c).

\subsection{The English Courts (for England and Wales)}

\footnotetext{
18 Thanks to Mark Symes for pointing out this recital in his skeleton argument. Mark Symes, 'Skeleton Argument, GS Afghanistan and Secretary of State for the Home Department', 4 July 2009, p.3 and p.9 (on file with the authors)

${ }^{19}$ Qualification Directive, Preamble, Recital (3).

${ }^{20}$ Qualification Directive, Preamble, Recital (10).

${ }^{21}$ Qualification Directive, Preamble, Recital (25).

${ }^{22}$ Qualification Directive, Preamble, Recital (11).
} 
The Qualification Directive has been implemented in the UK by the Refugee or Person in Need of International Protection (Qualification) Regulations SI 2006/2525 and the Statement of Changes in Immigration Rules, Cm6918. Article 15(c) of the Qualification Directive has so far been examined by the Asylum and Immigration Tribunal (AIT) and the Court of Appeal in the following cases: HH (Mogadishu: armed conflict: risk) Somalia CG [2008] UKAIT 00022, KH (Article 15c Qualification Directive) Iraq CG [2008] UKAIT 00023, AM \& AM (armed conflict: risk categories) Somalia CG [2008] UKAIT 03444, and GS (Article 15(c): indiscriminate violence) Afghanistan CG [2009] UKAIT 00044, before the Asylum and Immigration Tribunal, and $Q D \& A H$ (Iraq) v. Secretary of State for the Home Department [2009] EWCA Civ 620 (24 June 2009), before the Court of Appeal. ${ }^{23}$ In addition, the European Court of Justice (ECJ) gave its first (urgent) preliminary ruling on Article 15(c) on 17 February 2009 in the case Elgafaji (Justice and Home Affairs) C-465/07. With the exception of GS (Article 15(c): indiscriminate violence) Afghanistan CG decided by the AIT on 22-23 July 2009 and discussed in the context of assessing conflict severity and serious threats (section 5.), all other cases are discussed in this section below.

\subsubsection{The Asylum and Immigration Tribunal - pre-Elgafaji}

According to the AIT case-law predating the 2009 ruling from the ECJ in Elgafaji, most prominently $\mathrm{KH}$ (Iraq), ${ }^{24}$ key terms in Article 15(c) must be given an International Humanitarian Law (IHL) meaning. As a consequence, the phrase 'a civilian's life or person' must be interpreted through the lens of Common Article 3 of the 1949 Geneva Conventions, i.e., 'violence to life and person, in particular murder of all kinds, mutilation, cruel treatment and torture' but not 'threats which amount to inhuman and degrading treatment'. ${ }^{25}$ The AIT, however, accepted that 'the phrase must encompass the means for a person's survival'. ${ }^{26}$ And in $A M \& A M$ (Somalia), it recognized that: 'A person may be able to succeed in a claim to protection based on poor socio-economic or dire humanitarian living conditions under the Refugee Convention or Article 15 of the Qualification Directive or Article 3, although to succeed on this basis alone the circumstances would have to be extremely unusual'. ${ }^{27}$ The AIT also agreed that Article 15(c) must be regarded as having some scope additional to that contained in Article 15(a) and 15(b) ${ }^{28}$ - the 'added value' being that it is concerned not just with actual harm but also with a lesser form of harm, i.e., a threat of harm. ${ }^{29}$

The phrase 'by reason of indiscriminate violence' is concerned with violence closely related to the conduct of military operations (i.e., violence inflicted by combatants) and which violates the norms of IHL by failing to discriminate between military and civilian targets or because it

\footnotetext{
${ }^{23}$ In addition, the Court of Appeal decided Secretary of State for the Home Department v. HH (Iraq) [2009] EWCA Civ 727 (14 July 2009), a case raising issues under Article 15(c), yet these issues were not directly the subject of the appeal.

${ }^{24} \mathrm{KH}$ (Article 15(c) Qualification Directive) Iraq CG [2008] UKAIT 0002.

${ }^{25} \mathrm{KH}$ (Iraq), para.105.

${ }^{26} \mathrm{KH}$ (Iraq), para.104.

${ }^{27}$ AM \& AM (armed conflict: risk categories) Somalia CG [2008] UKAIT 03444, para.2.

${ }^{28} \mathrm{KH}$ (Iraq), para.29; AM \& AM (Somalia), paras.109, 179.

${ }^{29} K H$ (Iraq), paras.29 and 127.
} 
employs means which disproportionately affects civilians, or is random or untargeted in nature. ${ }^{30}$ Thus, certain types of violence are not covered by Article 15(c), such as, purely criminal violence, domestic violence, or any other type of non-military violence because they are not particularly of 'international concern'. ${ }^{31}$ In this regard, KH (Iraq) differs from HH (Somalia) in its finding that looting, for example, would not be covered by Article 15(c).

Moving on to the interpretation of 'individual', the leading authority on refugee protection in situations of armed conflicts (i.e., protection under Article 1A(2) of the 1951 Refugee Convention) is Adan. ${ }^{32}$ In this case, the House of Lords distinguished between two types of harm: harm inherent in the ordinary incidents of civil war (i.e., internal armed conflict) and harm involving risks over and above such incidents. However, not much was said about 'the critical factor which distinguishes persecution from the ordinary incidents of civil war' (as per Lord Lloyd). ${ }^{33}$ In relation to subsidiary protection (i.e., Article 15(c)), the AIT recognised that 'individual' threat or risk exists if there is a sufficiently serious threat or risk to all civilians so that 'merely being a civilian will not suffice; something more relating to the person's specific characteristics or profile or circumstances, must be shown'; ${ }^{34}$ they must be 'truly at risk'. ${ }^{35}$ However, the AIT 'does not require personal threats to an individual, or that they be at greater risk than are others'. ${ }^{36}$

In addition, $A M \& A M$ (Somalia) added to the discussion in $K H$ (Iraq) in two respects. One, it elaborated the causal requirement for a person to show a serious and individual threat ' $b y$ reason of' indiscriminate violence. The AIT explained that in order for the indiscriminate violence to be an 'effective cause', the serious harm does not have to be a direct effect of the indiscriminate violence, 'it is sufficient if the latter is an operative cause'. ${ }^{37}$ Thus, some kind of causal nexus is required that is more than only remote. ${ }^{38}$ Two, it expanded the analysis of the intensity of the violence. In this case, it was found that in addition to a worsening of the security situation, the humanitarian situation had deteriorated as characterised by mass displacement. ${ }^{39}$ Could such deterioration amount to persecution, serious harm or ill-treatment? ${ }^{40}$ The AIT explained that it is not just the number and geographical distribution of internally displaced persons (IDPs) that is of concern, it is also their treatment and denial of basic human rights; their movements are impeded

\footnotetext{
${ }^{30} \mathrm{KH}$ (Iraq), para.93.

${ }^{31} \mathrm{KH}$ (Iraq), paras.95-96.

${ }^{32}$ Adan $v$ Secretary of State for the Home Department [1998] 2 WLR 703.

${ }^{33}$ The Strasbourg Court has not excluded that in certain extreme circumstances, such circumstances could give rise to a violation of a non-derogable right ( $A M \& A M$ (Somalia), para.79). Furthermore, for ill treatment to arise under Art.3, it does not necessarily have to be intentional or deliberate. 'Hence, whilst there will always be heavy factual obstacles in the way of a finding that socio-economic circumstances can constitute persecution, there is no reason of principle why a claim of this kind cannot succeed' (para.79).

${ }^{34} \mathrm{KH}$ (Iraq), para.123.

${ }^{35}$ Symes, Skeleton Argument', p.6.

${ }^{36}$ Symes, Skeleton argument', p.6.

${ }^{37}$ AM \& AM (Somalia), para.3.

${ }^{38}$ AM \& AM (Somalia), para.97.

${ }^{39}$ AM \& AM (Somalia), paras.150-155.

${ }^{40}$ In $H H$ (Iraq), the AIT found that a person displaced from Mogadishu who was likely to have to spend any significant period of time in a makeshift shelter alongside the road to Afgoye, for example, or an IDP camp, may well experience ill-treatment under Article 3 ECHR ( $A M \&$ \& AM (Somalia), para.151, referring to HH (Iraq), para.299).
} 
by hundreds of checkpoints (where threats, intimidation, looting -and in the case of women and girls) rape, abduction and harassment can take place). A significant number of IDPs do not end in camps or makeshift settlements and are therefore subject to more insecurity (unable to obtain shelter, food, water, sanitation, or protection against rape, abduction and harassment). Finally, the effect of displacement also appears to reduce the ability of IDPs to count on protection of their own clan. The AIT was not, however, persuaded that 'the situation in central and southern Somalia generally has reached the threshold where civilians per se or Somali civilian IDPs per se can be said to face a real risk of persecution or serious harm or treatment proscribed by Article 3 $\mathrm{ECHR}^{41}$ for the following reasons: (1) the numbers of those killed and wounded are not of great magnitude; (2) it does not appear that civilians per se face a real risk of denial of basic food and shelter and other bare necessities of life (indeed many appear not to need humanitarian assistance and many who do need it, get help of some kind); (3) the great majority of the huge number of IDPs are able to travel and then subsist in IDP camps or settlements without serious setbacks.

The AIT then applied these 'principles' to the facts of the case, i.e., to the evidence gathered on the two applicants. The first applicant's appeal was dismissed on asylum, humanitarian protection (Article 15(c)) and human rights grounds (Article 15(b)) because it was found that he was from Jowhar, a town where the population is not in general exposed to serious harm and there was no longer any significant fighting there (as the insurgents have gained control of it). The second applicant's appeal was allowed on asylum and human rights grounds, and not Article 15(c), because he and his family members were from the Sheikhal Logobe clan, not a majority clan, thus he was unlikely to find protection from serious harm in Mogadishu if returned there from the UK. Hence, real risk of persecution (on grounds of race or ethnicity), serious harm and treatment contrary to Article 3 were found to exist and, in addition, there was no viable internal relocation alternative elsewhere in Somalia because this applicant had spent the last 5 years in the UK.

\subsubsection{The ECJ's ruling in the Elgafaji case}

Whilst the British courts were pursuing their search for the meaning of Article 15(c), the Dutch Raad van State was deciding a case that required it to consider the meaning of 'individual', a term not entirely clear at the time of adoption of the Qualification Directive, particularly in the light of Recital (26) and considering the context of 'indiscriminate violence. ${ }^{42}$ By application of Article 68 of the EC Treaty, the Raad van State referred questions to the ECJ for a preliminary ruling on the interpretation of this provision of EC law (i.e., Article 15(c)).

Consistent with UNHCR position, ${ }^{43}$ the ECJ in its ruling in Elgafaji (Justice and Home Affairs) ${ }^{44}$ favoured a liberal interpretation of an 'individual' threat that is situational or geographical rather than purely personal:

\footnotetext{
${ }^{41} A M \& A M$ (Somalia), para.156.

${ }^{42}$ UNHCR Statement on Subsidiary Protection under the EC Qualification Directive for People Threatened by Indiscriminate Violence, January 2008, pp.4-5.

Available at: http://www.unhcr.org/refworld/docid/479df7472.html [accessed 10 November 2009]

${ }^{43}$ UNHCR Statement on Subsidiary Protection under the EC Qualification Directive for People Threatened by Indiscriminate Violence, January 2008, p.6.

Available at: http://www.unhcr.org/refworld/docid/479df7472.html [accessed 10 November 2009]
} 
the word 'individual' must be understood as covering harm to civilians irrespective of their identity, where the degree of indiscriminate violence characterising the armed conflict taking place ... reaches such a high level that substantial grounds are shown for believing that a civilian, returned to the relevant country or, as the case may be, to the relevant region, would, solely on account of his presence on the territory of that country or region, face a real risk of being subject to the serious threat referred in Article 15(c) of the Directive (pararagraph 35)

According to the ECJ, such interpretation does not contradict the wording of Recital (26) since the word 'normally' in Recital (26) allows 'for the possibility of an exceptional situation which would be characterised by such a high degree of risk that substantial grounds would be shown for believing that that person would be subject individually to the risk in question'. ${ }^{45}$

This ruling is furthermore consistent with the European Court of Human Rights' judgment in Salah Sheekh $v$ The Netherlands in which it recognized that '[i]t might render the protection offered by that provision illusory if, in addition to the fact that he belongs to the Ashraf ..., the applicant be required to show the existence of further special distinguishing features'. ${ }^{46}$ And even more explicitly the European Court of Human Rights has now ruled in NA $v$ United Kingdom that:

...the Court has never excluded the possibility that a general situation of violence in a country of destination will be of sufficient level of intensity as to entail that any removal to it would necessarily breach Article 3 of the Convention. Nevertheless, the Court would adopt such an approach only in the most extreme cases of general violence, where there is a real risk of ill-treatment simply by virtue of an individual being exposed to such violence on return. ${ }^{47}$

It follows that in low level situations of indiscriminate violence, 'a clear degree of individualisation' is required under Article 15(c), namely 'the applicant will have to show that he is specifically affected [but not targeted ${ }^{48}$ ] by reason of factors particular to his personal circumstances'. ${ }^{49}$ Equally, in exceptionally high level situations of indiscriminate violence, the fact that the applicant comes from that geographical location would be sufficient to establish the existence of 'substantial grounds' that s/he would be subjected 'individually' to the risk in question. Thus, it has been argued 'Article 15c offer[s] more protective potential than simply addressing the plight of classes of civilians all equally at risk'. ${ }^{50}$ Moreover, past exposure to

See also UNHCR Submission in the Court of Appeal C5/2008/1706 on appeal from the AIT QD and AH (Iraq) $v$ Secretary of State for the Home Department, Annexure 1, para.31.

44 [2009] ECJ C-465/07 (17 February 2009).

45 ECJ, Elgafaji, para.37.

${ }^{46}$ Salah Sheekh $v$ The Netherlands, Application No.1948/04, 11 January 2007, para.148.

${ }^{47}$ NA v United Kingdom, Application No. 25904/07, 17 July 2008, para.115.

${ }^{48}$ ECJ, Elgafaji, para.43. This means that the applicant does not need to be singled-out.

${ }^{49}$ ECJ, Elgafaji, para.39.

${ }^{50}$ Symes, Skeleton Argument, p.7. 
violence from an armed conflict contributes to reducing the level of violence needed to be shown. ${ }^{51}$

The ECJ in Elgafaji also explained that 'Article 15(c) of the Directive is a provision, the content of which is different from that of Article 3 of the ECHR, and the interpretation of which must, therefore, be carried out independently, although with due regard for fundamental rights' as guaranteed in the ECHR ${ }^{52}$ Hence, the ECJ sees Article 3 ECHR protection 'as squarely provided by Article 15(b)' and recognises that Article 15(c) goes beyond Article 3; the key question is 'how much beyond? ${ }^{53}$ According to the ECJ, the harm defined in Article 15(c) (namely, a serious and individual threat to a civilian's life or person) 'covers a more general risk of harm' than the harm defined in Article 15(b) for instance which refers to more specific acts of violence. $^{54}$

The ECJ further dismissed an IHL reading of Article 15(c) and so rejected any reference made to violence that failed to observe the principles of IHL. As a result, it interpreted the phrase 'indiscriminate violence' as any form of violence which 'may extend to people irrespective of their personal circumstances, ${ }^{55}$

Finally, the ECJ appears to consider the element of 'serious' as relevant in order to define the gravity of the threat, namely, the severity of the armed conflict and resulting indiscriminate violence, as a defining element of 'individual'.

Notwithstanding the ruling of the ECJ which is binding on the Member States, states have retained some latitude in the overall interpretation of Article 15(c) as well as in the specific application of the ECJ ruling to the facts of the case at hand. For example, in $Q D \& A H$ (Iraq), the first case to have been decided by the Court of Appeal for England and Wales since the ECJ's ruling in Elgafaji, the Court held: "While this formulation [i.e., the interpretation of 'individual threat' by the ECJ] leaves open a very large area of factual judgment, it answers so far as can be done .... ${ }^{56}$

\subsubsection{The approach of the English Court of Appeal in $Q D \& A H$ (Iraq) - post-Elgafaji}

In the Court of Appeal, Sedley LJ disagreed with much of the AIT's approach to 'the true meaning and effect' of Article 15c adopted in KH (Iraq), which it nonetheless commended for its lucid and scholarly quality. Most notably, the Court of Appeal rejected an IHL reading of Article 15(c) because of differences in the object and purpose of international refugee law and IHL, preferring instead to regard the Qualification Directive as autonomous, i.e., as capable of 'stand[ing] on its two legs' ${ }^{57}$ This is an interpretation that is shared by Professor Goodwin-Gill:

\footnotetext{
${ }^{51}$ Symes, Skeleton Argument, p.7.

${ }^{52}$ ECJ, Elgafaji, para.28.

${ }^{53}$ Guy S. Goodwin-Gill, 'Challenges to the Protection of Refugees - Compliance with International Law', paper finalized for the Blackstone Chambers Asylum Law Seminar that took place on 31 March 2009 (on file with the authors).

${ }_{55}^{54}$ ECJ, Elgafaji, para.33.

${ }^{55}$ ECJ, Elgafaji, para. 34.

${ }^{56} Q D \& A H($ (Iraq), para.26.

${ }^{57} Q D \& A H($ Iraq), para. 18.
} 
'Given the object and purpose of Article 15(c) itself (protection from the risk of indiscriminate violence), the qualifying context ought to be one in which IHL may be illustrative, but cannot be determinative', 58 as well as UNHCR (Intervener before the Court of Appeal): 'whilst IHL law is a source of law that can inform the interpretation of Article 15(c), caution is warranted in seeking to draw too heavily on IHL', 59

The Court of Appeal also recognised that Article 15(c), 'both on its own and even more so when married with Article 2(e), is highly problematical' because of its 'poor drafting'. ${ }^{60}$ Such ambiguity is most apparent in the text of 'a real risk' of a 'threat', an 'individual threat' from 'indiscriminate violence', and an 'armed conflict' when 'there may well be only one source of indiscriminate violence'. ${ }^{61}$

On the first point, a 'risk' of a 'threat', the Court of Appeal opted for a pragmatic approach, finding that 'risk' in Article 2e overlaps with 'threat' in Article 15(c), 'so that the latter reiterates but does not qualify or dilute the former'. ${ }^{62}$ More specifically on the issue of the seriousness of the threat or harm, the Court of Appeal considers that Article 15(c) is 'intelligibly concerned with serious threats of real harm', ${ }^{63}$ i.e., those 'endemic acts of indiscriminate violence', such as the placing of car bombs in market places and snipers firing methodically at people in the streets. It is less concerned about fear resulting from 'threats of violence the primary purpose of which is to spread terror among the civilian population'. ${ }^{64}$ In seeking to determine the kind or degree of risk to individuals required to bring a situation of armed conflict within the purview of Article 15(c), the Court of Appeal found that the threshold of risk was set too high in $K H$ (Iraq) ${ }^{65}$ It rejected the requirement of a 'consistent pattern' (expressed in $A A$ (Zimbabwe)) ${ }^{66}$ on the ground that 'The risk of random injury of death which indiscriminate violence carries is the converse of consistency' ${ }^{67}$ In this regard, it may be recalled that the ECJ's ruling stated that 'The "threat [...] to a civilian's life or person" in Article 15(c) is more general than specific acts of violence and "that threat is inherent in a general situation of "international or internal armed conflict"" ${ }^{68}$ As discussed below, this is also the interpretation adopted by the French courts.

\footnotetext{
${ }^{58}$ Goodwin-Gill, 'Challenges to the Protection of Refugees - Compliance with International Law', paper finalized for the Blackstone Chambers Asylum Law Seminar that took place on 31 March 2009 (on file with the authors), para. 10.

${ }^{59}$ UNHCR Submission, Annexure 1, in $Q D \& A H$ (Iraq), para.20.

${ }^{60} Q D \& A H($ Iraq), para. 19.

${ }^{61} Q D \& A H$ (Iraq), para. 19.

${ }^{62} Q D \& A H$ (Iraq), para.29. This is consistent with UNHCR's submission to the Court of Appeal in this case, and which does not separate Article 15(c) from Article 2(e) and thus considers that 'in order for a person to benefit from SPS [subsidiary protection status] under Article 15(c), the Court must be satisfied that there is a "real risk" of a "serious...threat to an individual's life or person"" (UNHCR's submission, Annexure 1, para.46). Hence, "serious" threat helps to define the severity of the harm at risk - serious threat should not be read as an additional element to the real risk test. UNHCR Submission, Annexure 1, para.56.

${ }^{63} Q D \& A H$ (Iraq), para. 31 .

${ }^{64} Q D \& A H$ (Iraq), para.28.

${ }^{65} Q D \& A H$ (Iraq), para. 18.

${ }^{66}$ AA (Zimbabwe) [2007] EWCA Civ 149.

${ }^{67} Q D \& A H$ (Iraq), para.32.

${ }^{68} Q D \& A H$ (Iraq), para.34.
} 
On the second point, 'individual threat' from 'indiscriminate violence', the Court of Appeal embraced the ECJ's ruling in Elgafaji, namely,

the word 'individual' must be understood as covering harm to civilians irrespective of their identity, where the degree of indiscriminate violence characterising the armed conflict taking place ... reaches such a high level that substantial grounds are shown for believing that a civilian, returned to the relevant country or, as the case may be, to the relevant region, would, solely on account of his presence on the territory of that country or region, face a real risk of being subject to the serious threat referred in Article 15(c) of the Directive (paragraph 35, Elgafaji)

The Court of Appeal explained that with this ruling, 'the ECJ has sought to reconcile two things which Advocate-General Maduro in his Opinion (\$31) has described as seeming "prima facie irreconcilable" - an individual threat arising from indiscriminate violence'. ${ }^{9}$ The Court of Appeal further explained that the use of word 'exceptionally' meant that not every armed conflict or violent situation will attract the protection of Article 15(c), but rather only the most violent situations will result in civilians as a population or group being able to show a real risk to their life or person under Article $15(\mathrm{c}) .^{70}$ As for the term 'by reason of indiscriminate violence', it implies that 'without anything to render them a particular target, civilians face real risks to their life or personal safety'.71

UNHCR, in its submission to the Court of Appeal as Intervener, explained: 'From the perspective of refugee/human rights law, the distinction between violence employed against military targets and civilians is a false one. The correct distinction is between violence giving rise to a well-founded fear of persecution and violence that does not but which nonetheless gives rise to the need for international protection outside the regime of the 1951 Refugee Convention'. 72 UNHCR thus highlighted a protection gap resulting from $K H$ (Iraq): 'where armed conflict leads to a break down in law and order leading to endemic criminal violence, those fleeing would be unable to claim SP because the violence would not be committed against civilians in breach of the Geneva Conventions'. ${ }^{73}$ And yet, refugee law and human rights law protect against persecution or treatment inflicted by non-state actors. ${ }^{74}$ This is an important point because in many conflicts it is in fact very difficult to distinguish between threats of violence emanating from combatants and those deriving from mere criminals. Indeed there is nothing in Article 15(c) limiting the source of violence as long as it arises in the context of an armed conflict. This is because refugee law/human rights law imposes obligations on host states, and not on the parties to an armed conflict.

\footnotetext{
${ }^{69} Q D \& A H$ (Iraq), para.25.

${ }^{70} Q D \& A H$ (Iraq), para.25.

${ }^{71} Q D \& A H$ (Iraq), para. 25.

${ }^{72}$ UNHCR Submission, Annexure 1, para.45.2.

${ }^{73}$ UNHCR Submission, Annexure 1, para.45.3.

${ }^{74}$ E.g., Horvath $v$ Secretary of State for the Home Department, House of Lords, judgment of 6 July 2000, [2001] 1 AC 489 (a refugee law case), and D. $v$ UK (European Court of Human Rights, judgment of 2 May 1997) and N. $v$ $U K$ (European Court of Human Rights, judgment of 27 May 2008), both human rights law cases.
} 
On the third point, 'armed conflict' when 'there may well be only one source of indiscriminate violence', the Court of Appeal accepted the proposition agreed upon by both parties as well as the UNHCR as Intervener, that the phrase 'situations of international or internal armed conflict' in Article 15(c) 'has an autonomous meaning broad enough to capture any situation of indiscriminate violence, whether caused by one or more armed factions or by a state, which reaches the level described in Elgafaji ${ }^{75}$ The Court of Appeal then clarified that there was "no requirement that the armed conflict itself must be exceptional. What is, however, required is an intensity of indiscriminate violence - which will self-evidently not characterise every such situation - great enough to meet the test spelt out by the ECJ', ${ }^{76}$ i.e., the 'substantial grounds' and 'real risk' tests as expressed in paragraph 35 of the ECJ's ruling. And the Court of Appeal specified that a civilian within the context of Article 15(c) means any 'genuine noncombatants'; ${ }^{7}$ the UNHCR also includes within this terminology 'former combatants who can demonstrate that they have renounced military activities'. ${ }^{78}$

The Court of Appeal concluded by considering 'the critical question, in the light of the Directive' to be:

'Is there in Iraq or a material part of it such a high level of indiscriminate violence that substantial grounds exist for believing that an applicant such as QD or AH would, solely by being present there, face a real risk which threatens his life or person? ${ }^{, 79}$

In sum, the English courts' case-law reveals the following elements:

- Article 15(c) may not be read in the light of IHL

- Article 15(c) is concerned with serious threats of real harm and does not require a consistent pattern of risk

- Only the most violent situation will attract the protection of Article 15(c); there is no need to show that an individual is particularly targeted

- In cases of armed conflict, the key, determining element should be the intensity of indiscriminate violence - which is not the same thing as the requirement that the armed conflict be exceptional. Such intensity may find evidence in a worsening of the security situation or a deterioration of the humanitarian situation as characterised by mass displacement.

\subsection{The French courts}

The meaning of Article 15(c) has also been examined by the French courts on numerous occasions, particularly by the Refugee Appeal Tribunal (Commission de Recours des Réfugiés CRR), now the National Asylum Court (Court Nationale du Droit d'Asile - CNDA), and by the Conseil d'Etat. Decisions from the French courts are not as informative as decisions from the English courts in their legal reasoning. However, useful information can be found in conclusions

${ }_{76}^{75} Q D \& A H($ Iraq $)$, para. 35.

${ }^{76} Q D \& A H$ (Iraq), para.36.

${ }_{78}^{77} Q D \& A H$ (Iraq), para.37.

${ }^{78}$ UNHCR Statement on Subsidiary Protection under the EC Qualification Directive, January 2008, p.7. See also UNHCR Submission, Annexure 1, in $Q D \& A H$ (Iraq).

${ }^{79} Q D \& A H($ Iraq), para.40. 
of the Commissaire du Gouvernement who, as members of the Conseil d'Etat, represent the public interest in a given case. It is their task, in tandem with the other judges, to survey the law on a particular issue and to present their personal opinion. Their role is only advisory but, unlike in civil cases, it is a principle of administrative procedure that the Commissaire du Gouvernment provides a reasoned opinion in all administrative cases. ${ }^{80}$

Article L.712-1 Cedesa (Code de l'entrée et du séjour des étrangers et du droit d'asile) ${ }^{81}$ provides that the Office Français de Protection des Réfugiés et Apatrides (OFPRA) shall grant subsidiary protection to asylum seekers who do not meet the requirements laid down by the refugee definition but who have proved that they could be exposed to one of the following serious threats (menaces graves):

[...] (c) serious, direct and individual threat to a civilian's life or person by reason of generalised violence (violence généralisée) in situations of international or internal armed conflict.

French legislation (i.e., Article L.712-1c Cedesa) - and French jurisprudence on Article 15(c) therefore does not use the phrase 'indiscriminate violence' as provided in the Qualification Directive. Rather it uses 'generalised violence' as provided in the Directive on Temporary Protection. Furthermore, French legislation adds to the requirements of 'serious and individual threat' that of 'direct'.

The French courts have adopted a more flexible approach towards IHL than the Court of Appeal (for England and Wales) and the ECJ, when interpreting Article 15(c), as illustrated by the two following examples. In M. Azzine Ahmed, ${ }^{82}$ the then Refugee Appeal Tribunal recognised that the applicant had left a situation of indiscriminate violence resulting from the existence of an internal armed conflict in Darfur as provided by Article 3 of the Geneva Convention of 12 August 1949. In M. Baskarathas, the Conseil d'Etat simply noted that the different parties to the conflict (including LTTE members and national army forces) were all guilty of grave breaches of IHL towards civilians. However, M. Julien Boucher, Commissaire du Gouvernment in this case, referred to a number of IHL provisions and reports. ${ }^{83}$ Thus, it has been said that, at the very least, IHL is used in 'spirit', that is, the idea that non-combatants should be kept away from the fighting and that combatants should not kill or threaten them. ${ }^{84}$ This means that if violence is generalised or indiscriminate, civilians are not kept away or protected, and therefore they are in need of protection. In the words of Sophie Albert: 'subsidiary protection supplements unapplied IHL in conflict - Article 15(c) is necessary when IHL is not in force. That is the spirit of the

\footnotetext{
${ }^{80}$ See John Bell, French Legal Cultures (London: Butterworths, 2001), p. 160, and John Bell, Judiciaries within Europe - A Comparative Review (Cambridge University Press, 2006), pp. 75 and 82.

${ }^{81}$ To read more on subsidiary protection in France, in particular on issues of transposition, see Vera Zederman, 'The French reading of subsidiary protection', Commission des Recours des Réfugiés, Part II(A): France, pp.18-19, in International Association of Refugee Law Judges, Convention Refugee Status and Subsidiary Protection Working Party - First Report, IARLJ $7^{\text {th }}$ World Conference, Mexico City, November 2006.

${ }^{82}$ Application no.538807, 22 November 2005.

${ }^{83}$ E.g., the 1977 Second Additional Protocol to the 1949 Geneva Conventions on the protection of victims of noninternational armed conflicts (Article 1). To read more on this, see Roger Errera, 'The ECJ and Subsidiary Protection: Reflections on Elgafaji - and After', Paper for the European Asylum Law Judges Association European Academy Workshop, Berlin, October 19-20, 2009 (on file with the authors).

${ }^{84}$ Email correspondence with Dr. Sophie Albert, Head of the Litigation Section of the Legal Affairs Division at the French Office for the protection of Refugees and Stateless Persons (OFPRA), 25 September 2009.
} 
subsidiary protection regime'. ${ }^{85}$ This reasoning by the French courts has the advantage of situating Article 15(c) in relation to IHL.

French case-law on the risk or threat arising from situations of armed conflict is further characterised by an overlap between refugee protection and subsidiary protection. It has been observed that 'the existence of an armed conflict is not an obstacle to refugee status recognition and [Article 15(c)] is not necessarily the standard for those fleeing from a war'. ${ }^{86}$ This jurisprudence goes back to a decision of the Conseil d'Etat from 1997, finding that situations of armed conflict (in this case (the former) Yugoslavia, particularly Sarajevo) could, in principle, create a fear of persecution within the meaning of Article $1 \mathrm{~A}(2)$ of the Refugee Convention. ${ }^{87}$ With this decision, the Conseil d'Etat put an end to the jurisprudence of the Refugee Appeal Tribunal developed over many years and according to which dangers arising from a 'state of war' or a 'civil war' did not as such constitute risks of persecution within the meaning of the Refugee Convention. ${ }^{88}$

This overlap is further emphasised by the fact that under both the Refugee Convention (i.e., case law) and the Qualification Directive (i.e., the text of Article 15(c)), the risk of persecution or threat to a civilian's life or person must be 'individual'. Thus, in Mlle Strbo, a case about protection under the Refugee Convention, the applicant was refused refugee status because she had failed to show a 'fear of persecution of a personal character', having based her fear instead on 'the general situation in that city [Sarajevo]' ${ }^{89}$ However, an 'individual' fear of persecution was found with regard to Mrs Adamovic because she could show that 'she had just scraped out from an attempt that killed one of her colleagues'. ${ }^{90}$ Article 15(c) Qualification Directive too requires the threat to a civilian's life or person to be 'individual'. In addition, the threat has to be 'serious' (Article 15(c), Qualification Directive) and 'direct' (Article L.712-1c, Ceseda). French jurisprudence tends to look at all three elements together. For instance, in M Azzine Ahmed, the then Refugee Appeal Tribunal recognised that the applicant, who had left a situation of indiscriminate violence resulting from the existence of an internal armed conflict in Darfur, was subject to a serious, direct and individual threat against his life 'by reason of his noteworthy and well-off position'. ${ }^{91} \mathrm{He}$ was therefore granted subsidiary protection. In a most recent decision, M. Baskarathas, ${ }^{92}$ the Conseil d'Etat, embracing the meaning of 'individual' as elaborated by the ECJ in Elgafaji, recognised that 'a serious, direct and individual threat' is not subordinated to the applicant having to show that $\mathrm{s} /$ he is specifically targeted by reason of some particular

\footnotetext{
${ }^{85}$ Ibid.

${ }^{86}$ Laurent Dufour, 'The 1951 Refugee Convention and Subsidiary Protection: Uncertain Boundaries', Commission des Recours des Réfugiés, Part II(B): France, in International Association of Refugee Law Judges, Convention Refugee Status and Subsidiary Protection Working Party - First Report, IARLJ $7^{\text {th }}$ World Conference, Mexico City, November 2006, at p.34.

${ }^{87}$ Conseil d'Etat, Mlle Strbo, 12 May 1997.

${ }^{88}$ CRR, Miss Abbas-Akarim, 10 February 1984, in the context of the Iran-Iraq war, and CRR, Zein El Abiddine, 13 June 1985, in the context of the Lebanese civil war; both cited in Laurent Dufour, 'The 1951 Refugee Convention and Subsidiary Protection: Uncertain Boundaries', Commission des Recours des Réfugiés, Part II(B): France, pp.3334, in International Association of Refugee Law Judges, Convention Refugee Status and Subsidiary Protection Working Party - First Report, IARLJ $7^{\text {th }}$ World Conference, Mexico City, November 2006.

${ }^{89}$ Ibid, Dufour, at p.34. Conseil d'Etat, 12 May 1997, application no. 154321, Mlle Strbo, p.188.

${ }^{90}$ Ibid, Dufour, at p.34, referring to Conseil d'Etat, Mme Adamovic, 12 May 1997.

${ }^{91}$ Application no.538807, 22 November 2005.

${ }^{92}$ Application no. 320295, 3 July 2009.
} 
characteristics of her/his own where the degree of indiscriminate violence - characterising the armed conflict - is such that there exist serious reasons for believing that a civilian would be at real risk of a threat (as defined in Article 15(c)) by his/her mere presence on that territory. Its Commissaire du Gouvernement, M. Julien Boucher, explained that in other situations where the level of violence is not as high (or exceptional), the court would need to consider elements that are specific or particular to the individual applicant. ${ }^{93}$

The notion of 'individual' threat was further clarified by the Commissaire $d u$ Gouvernement, Mme Julie Burguburu, in her conclusions in the case Mlle Bernadette Kona. ${ }^{94}$ Article L.712-1 provides that an asylum seeker must prove that 'they could be exposed to one of the following serious threats'. According to Mme Burguburu, the use of the word 'exposed' (exposée) entails an 'individual' element. Referring to the ECJ's ruling in Elgafaji, she then explains that it is the reason at the origin of the threat, i.e., the indiscriminate violence and its severity, which justifies subsidiary protection under the Qualification Directive. Hence, it is unnecessary for an asylum seeker to be specifically targeted.

The overlap between refugee protection and subsidiary protection finds another illustration in the Refugee Appeal Tribunal's requirement of the inability to seek protection from the state authorities in order to be eligible for subsidiary protection. For instance, in Mlle Rincon Perez, the Tribunal granted subsidiary protection to an applicant from Colombia who, as an accountant, had been employed by her parents, land owners in a region occupied by the FARC rebels in $2001{ }^{95}$ Her cousins had been shot dead by the insurgents. She herself had been the subject of pressures and death threats. Such threats were found to be linked to a general climate of indiscriminate violence resulting from a situation of internal armed conflict prevailing at the time in that region of Colombia, without her being able to seek protection from the state authorities.

The Conseil d'Etat further considers that the concept of 'generalised violence' (violence généralisée) - at the origin of a threat upon which an application for subsidiary protection is based - is inherent to a situation of armed conflict (internal or international) and in fact characterises it. ${ }^{96}$ Its Commissaire $d u$ Gouvernement, M. Julien Boucher, explained:

'It would be to disregard the reality of modern armed conflicts to pretend that resulting violence occurs only on the battlefield, which itself is difficult to define since ordered battle has given way to skirmish wars.' (Lambert translation)

The Conseil d'Etat then recognised that the existence of 'generalised violence' in the form of violent attacks and other particularly cruel acts against civilians in the area of Sri Lanka where the applicant is from, forced civilians to be displaced. This interpretation by the Conseil d'Etat confirms previous jurisprudence by the Refugee Appeal Tribunal/National Asylum Court. For instance, in M. Alazawi, the Refugee Appeal Tribunal found that the situation prevailing (at the

\footnotetext{
${ }^{93}$ Conseil d'Etat, M. Baskarathas, Application no.3 20295, 3 July 2009, Conclusions du Commissaire du Gouvernment Julien Boucher.

${ }^{94}$ Conseil d'Etat, Mlle Bernadette Kona, Application no. 292564, 15 May 2009, Conclusions du Commissaire du Gouvernement Julie Burguburu.

9529 September 2006.

${ }^{96}$ Conseil d'Etat, M. Baskarathas, Application no. 320295, 3 July 2009.
} 
time) in Iraq was characterised by general violence as evidenced by certain cruel acts against civilians, such as, violent attacks, killings, kidnappings and muggings. ${ }^{97}$ It also found that this situation was the result of the conflict between Iraqis security forces, Coalition forces, and certain armed groups, under responsible command, exercising control over a part of the territory and carrying out sustained and concerted military operations. This situation must therefore be regarded as one of generalised violence resulting from a situation of internal armed conflict.

Considering the amount of overlap between refugee protection and subsidiary protection, the Conseil d'Etat was recently confronted with the problem of having to clarify the relationship (i.e., the scope of application) between refugee protection status and subsidiary protection status in cases of armed conflict. In the case Mlle Bernadette Kona ${ }^{98}$ the Conseil d'Etat quashed a decision from the National Asylum Court which had denied refugee status to an applicant from Iraq on the ground that the situation of indiscriminate violence in Iraq meant that she should (only) be granted subsidiary protection even though the National Asylum Court recognised that the violence she feared resulted from her membership to a particular community ('Christian Assyro-Chaldean') as well as her situation as a well-off, single woman. According to the Conseil d'Etat, her membership to a particular social group should have brought her clearly within the scope of Article 1A(2) of the Refugee Convention. This decision thus re-affirms the primacy of protection under the Refugee Convention as stated in the Qualification Directive, Preamble, Recital (3), (5) and (24). In other words, if membership to a particular social or ethnic group can be shown and linked to the fear of being persecuted, this element shall prevail over the existence of an armed conflict, unless the membership ground is too remote from the fear of being persecuted. This interpretation must be welcome for it puts an end to a long-standing practice by the Refugee Appeal Tribunal/National Asylum Court according to which threats resulting from a situation of indiscriminate violence ('violence généralisée'), even on a Refugee Convention ground, should not give rise to protection under the Refugee Convention. ${ }^{99}$ According to the Commissaire du Gouvernement, Mme Julie Burguburu, in this case, the two statuses (Refugee Convention and subsidiary protection) do not in fact differ depending on the intensity of the threat. Rather they each have their own distinct scope of application which is determined by the grounds (or reasons) for the risks incurred. Such a reading of Article L.712-1-c) would have the benefit to reduce the scope of application of subsidiary protection, since many armed conflicts are based on ethnic or religious grounds, as well as to increase the number of cases of protection under the Refugee Convention.

In sum, French jurisprudence reveals the following characteristics:

- A flexible approach towards the role of IHL in the reading of Article 15(c) - IHL is used in spirit.

- 'Generalised violence' (violence généralisée) - at the origin of a threat upon which an application for subsidiary protection is based - is inherent to a situation of armed conflict (internal or international) and in fact characterises it. The Conseil d'Etat has in this

\footnotetext{
${ }^{97}$ Application no. 497089, 17 February 2006.

98 Application no. 292564, 15 May 2009.

99 E.g., CRR, sections réunies, 9 October 1998, M. Maxamed, cited in Vera Zerderman, 'The French reading of subsidiary protection', Commission des Recours des Réfugiés, Part II(A): France,at p.25, in International Association of Refugee Law Judges, Convention Refugee Status and Subsidiary Protection Working Party - First Report, IARLJ $7^{\text {th }}$ World Conference, Mexico City, November 2006.
} 
context referred to the forced displacement of civilians as evidence of the existence of 'generalised violence'.

- In cases of armed conflict, the key distinguishing element between subsidiary protection and refugee protection is the absence (or existence of) a Refugee Convention ground; it is not the existence (or not) of an armed conflict nor the 'individual' character (or not) of the threat or fear of persecution.

Yet, it is not always easy to show an 'individual' threat without having recourse to a Refugee Convention ground. Furthermore, many armed conflicts are based on ethnic or religious ground, hence one ends up wondering about the usefulness of Article 15(c) protection in cases of armed conflict. The practice of the French courts reveals that subsidiary protection is very much what is says it is: subsidiary. Since its adoption, Article L.712-2-c) has been used to provide subsidiary protection to persons who fled the conflicts in Afghanistan, Iraq, Sri Lanka, Colombia, Somalia and Sudan but only in non-typical cases, i.e., where people were victims of cross-fire or looting. Most asylum seekers coming from these countries have been granted refugee status based on one of the Refugee Convention grounds. The latest decision by the Conseil d'Etat in Mlle Bernadette Kona seems to suggest that this trend will continue.

\section{THE CHANGING CHARACTER OF ARMED CONFLICT AND THE RISE OF HUMAN SECURITY}

Article 15(c) raises the question of what is an armed conflict. Strictly speaking, this question remains unanswered in international law, as there is still 'no authoritative definition of armed conflict in international law'. ${ }^{100}$ However a working definition has been offered from two authoritative sources. The Appeals Chamber of the International Criminal Tribunal of Yugoslavia (ICTY) in Tadic held that

an armed conflict exists wherever there is a resort to armed force between states or protracted armed violence between governmental authorities and organised armed groups or between such groups within a state. (paragraph 70) ${ }^{101}$

Drawing on this and other decisions by the ICTY, as well as interpretations of convention and customary law by recognized authorities, the International Committee of the Red Cross recently offered the following as an authoritative definition:

Non-international armed conflicts are protracted armed confrontations occurring between governmental armed forces and the forces of one or more armed groups, or between such groups arising from the territory of a state [party to the Geneva Conventions]. The armed confrontation must reach a minimum level of intensity and the parties involved in the conflict must show a minimum level of organization. ${ }^{102}$

\footnotetext{
${ }^{100}$ Natasha Balendra, 'Defining Armed Conflict', Cardozo Law Review 29 (6) 2008, pp.2461-2516, at p.2463.

${ }^{101}$ Case No.IT-94-1-T, judgment of 2 October 1995 (jurisdiction).

${ }^{102}$ International Committee of the Red Cross (ICRC), Opinion Paper, "How is the Term "Armed Conflict" Defined in International Humanitarian Law?', March 2008, p. 5.

Available at: http://www.icrc.org/web/eng/siteeng0.nsf/htmlall/armed-conflict-article-170308/\$file/Opinion-paperarmed-conflict.pdf [last accessed 10 November 2009]
} 
The AIT has, in the past, adopted a definition of armed conflict which is consistent with those offered by the ICTY and ICRC. In KH (Iraq), the Tribunal found that four matters needed to be investigated in making a determination about the existence of an internal armed conflict: the parties to the conflict; their degree of organization; the level of intensity in violence; and the protraction of the violent confrontation. As we discuss above, the Court of Appeal (for England and Wales) subsequently rejected the application of IHL by the AIT in interpreting the Qualification Directive. Both the Court of Appeal (for England and Wales) and the French courts agree that the determining element should be the intensity of indiscriminate violence which characterises an armed conflict. Thus they have concentrated on the two key issues which concern the application of Article 15(c) of the Qualification Directive: namely, the severity of the conflict in question and the attendant seriousness of risk to individuals fleeing the conflict. As it happens there has been much debate within academia in recent decades over the changing character of armed conflict in recent decades and over how to conceptualise security for individuals. Both issues have direct bearing on both how to assess conflict severity and how to assess the seriousness of risks to individuals.

\subsection{New Wars and Human Security}

Throughout the Cold War, the focus of Strategic Studies (a subfield of International Relations, a discipline which itself originated in the study of war) was on the national security of states and the study of interstate war. However, during the 1980s, progress in US-Soviet arms control and the promotion of the concept of common security by Soviet Premier Gorbachev, began to shift scholarly attention from the challenges of national to international security. At the end of the Cold War, the traditional concerns in the academic study of war were replaced by new security challenges associated with the decline of centralized state institutions and the dissolution of federal states. In response, the focus of Strategic Studies broadened to include internal as well as international armed conflict. The 1990s saw the subfield re-branded Security Studies, as it expanded to take in a range of issues including economic, political, societal and environmental security. ${ }^{103}$

The 1990s also saw the rise of what were termed 'New Wars.' Some of these conflicts were developing world legacies from the Cold War (e.g., Afghanistan, Cambodia, Nicaragua and El Salvador); some were wars that coincided with the end of the Cold War (e.g., the wars of central Africa and the former Yugoslavia). All suggested that the character of war had changed from the modern form of high-tech and state-on-state warfare, to a pre-modern form of mostly low-tech and trans-state warfare. These new wars have been messy affairs involving a broad range of military actors, including insurgents, militias, and criminals, as well as state-based military forces. New wars are not waged for reasons of state but rather for a mix of motives involving greed and grievance: wars are fought to secure resources, and to avenge for perceived past wrongs. Moreover, these new wars are characterised by the blurring of the traditional boundaries of war in terms of space, time and participants. Where traditionally war was defined by state borders, with clearly defined states fighting to control territory, new wars are waged within and across state borders. Indeed, the label 'civil war' disguises the direct role usually played by

\footnotetext{
${ }^{103}$ Barry Buzan, People, States and Fear: An Agenda for International Security in the Post-Cold War Era, $2^{\text {nd }}$ edn, London, 1991; see also Theo Farrell, 'General Introduction', Security Studies, volume I (London: Routledge, 2010).
} 
neighbouring states in such wars, as well as the trans-border political economy of such wars. Where war is traditionally distinguished from time of peace (indeed, these separate conditions are built into the fabric of international law), the new wars just rumbled endlessly on. War may be punctuated by periods of fragile and relative peace but peace rarely lasts. Finally, the lines between military and civilian are blurred in the new wars. These are wars without clear battlefronts and home-fronts, and where combatants are not easily distinguished from civilians. Indeed, the forces of rival factions often involve a mix of former soldiers, forcibly conscripted civilians, and criminals. ${ }^{104}$ Moreover, a number of these new wars have been waged not only amongst civilians but also against civilians. This is evident in the conflicts in the Balkans, Chechnya, Columbia, Burundi, Rwanda, the Democratic Republic of the Congo, Liberia and Sierra Leone. To be sure, civilians have been targeted in wars past, but the centrality of civilian targeting is characteristic of the wars of the $1990 \mathrm{~s} .{ }^{105}$ Often the goal is to terrorise and thereby control or expel particular population groups, and so these new wars have not actually proven more lethal for civilians than the great industrial wars of centuries past. ${ }^{106}$ That said, as we argue later, civilian death is an insufficient measure of the level of civilian insecurity in armed conflict.

Alongside the 'broadening' of post-Cold War Security Studies to include a new focus on socalled internal armed conflict (as well as non-military areas of security), there was also a 'deepening' of the concept of security. Most significant here has been the rise of the human security paradigm in Security Studies. This represents a whole new way of thinking about security, not in terms of securing states but in terms of providing security for people, broadly defined to include 'freedom from want, freedom from fear and freedom to take action on one's own behalf' ${ }^{107}$ This broader definition refers to the right of individuals 'to live in safety and dignity and to earn a livelihood'. ${ }^{108}$ The human security paradigm also challenges the traditional primacy afforded to state sovereignty and our understanding of sovereign legitimacy in providing that 'the state - and state sovereignty - must serve and support the people from which it (in theory) draws its legitimacy'. ${ }^{109}$ The human security concept therefore does two things: it focuses directly and specifically on the individual, and it views threats to the physical integrity of individuals as security threats.

There are a number of approaches to the human security paradigm. One recent review suggests four: the 'broad approach' (which considers all threats to human integrity, such as poverty, disease, and climate change); a 'narrower approach' which considers the 'human consequences of armed conflict and the dangers posed to civilians by repressive governments and situations of

\footnotetext{
${ }^{104}$ Martin Van Crevald, The Transformation of War (New York: The Free Press, 1991), Mary Kaldor, New and Old Wars (Cambridge: Polity, 1999); John Mueller, The Remnants of War (Ithaca, NY: Cornell University Press, 2004), Herfried Munkler, The New Wars (Cambridge: Polity, 2005).

${ }^{105}$ Kaldor, New and Old Wars, pp.7-8; Rupert Smith, The Utility of Force: The Art of War in the Modern World (London: Allen Lane, 2005); Hugo Slim, Killing Civilians: Method, Madness and Morality in War (London: Hurst, 2007); Alexander B. Downes, Targeting Civilians in War (Ithaca, NY: Cornell University Press, 2008).

${ }^{106}$ Erik Melander, Magnus Oberg, and Jonathan Hall, ‘Are “New Wars” More Atrocious?' European Journal of International Relations, 15 (2009), pp.505-536.

${ }^{107}$ UN Commission on Human Security, Human Security Now: The Final Report of the Commission on Human Security, 1 May 2003, at http://www.humansecurity-chs.org/finalreport/index.html

${ }^{108}$ Alice Edwards, 'Human Security and the Rights of Refugees: Transcending Territorial and Disciplinary Borders', Michigan Journal of International Law 30 (2009), pp.763-807, at p.765.

${ }^{109}$ Paul Williams, 'Human Security', in Robert Denmark (ed.), The International Studies Association Compendium Project (Blackwells, forthcoming), at page 8 of draft transcript (on file with the authors).
} 
state failure'; an 'umbrella approach' which considers a range of 'non-traditional' security issues (e.g., HIV/AIDS, drugs, environment, terrorism, human trafficking etc.; and finally a 'theoretical approach' ${ }^{110}$ Distinction may also be drawn between material and non-material approaches to human security ${ }^{111}$ - with the former including physical threats whose impact can be measured (e.g., civilian casualties) with physical survival as 'the bottom line', and the latter focusing on threat to values such as well-being and human dignity. ${ }^{112}$ In this article, we apply a narrow, material approach, this being the most minimal approach to human security, and consequently the one which might be most expected to be accommodated within international protection law and practice.

As noted, academics developing the human security paradigm have drawn on theoretical approaches to International Relations (i.e., 'Critical IR Theory') that question the primacy afforded to states and state concerns in the study of world politics. ${ }^{113}$ In its 1994 annual report, the UN Development Programme (UNDP) stated that the concept of security had up until now been too narrowly construed and needed expanding beyond the concepts of national security or territorial integrity 'to an all-encompassing [trans-boundary] concept' ${ }^{114}$ It presented the 'idea of human security' as 'likely to revolutionize society in the $21^{\text {st }}$ century' ${ }^{115}$ because

It means, first, safety from such chronic threats as hunger, disease and repression. And second, it means protection from sudden and hurtful disruptions in the patterns of daily life. ${ }^{116}$

As this UNDP annual report suggests, the direction of academic debate has paralleled increasing political and public concern with the fate of non-nationals. Indicative of this trend is the postCold War state practice of humanitarian intervention, and activism by non-governmental organisations in promoting the responsibility of states to prevent atrocities. ${ }^{117}$ The 1999 Kosovo War proved to be a key test case because there was a clear absence of legal grounds for the use of force but, nonetheless, a large coalition of democracies used force for humanitarian purpose, and this purpose was recognised by many other states in the international community, even if the legality of the action was not. ${ }^{118}$ In April 2000, the UN Security Council passed resolution 1296 launching an agenda to monitor and promote the protection of civilians in conflict. ${ }^{119}$

These two developments - the rise of 'new wars' and of the human security paradigm - have great significance for how one measures the severity of armed conflict and the risk to individuals seeking refuge from such conflict. The traditional measure of conflict severity is battle dead.

\footnotetext{
${ }^{110}$ Williams, pages 8-12 draft transcript.

${ }^{111}$ Williams, at page 12 draft transcript.

112 Williams, at page 13 draft transcript.

113 Bill McSweeney, Security, Identity and Interests: A Sociology of International Relations, Cambridge, 1999; Ken Booth, Theory of World Security, Cambridge, 2007.

${ }^{114}$ UNDP, Human Development Report: New Dimensions of Human Security, 1994, Chap.2, at p.24

115 Ibid, at p.22.

116 Ibid, at p.25.

${ }^{117} \mathrm{http}: / /$ www.responsibilitytoprotect.org/

118 Bruno Simma, 'NATO, the UN and Use of Force: Legal Aspects,' European Journal of International Law 10 (1999), pp.6-14; Antonio Cassese, 'A Follow-Up: Forcible Humanitarian Countermeasures and Opinio Nessitantis,' European Journal of International Law 10 (1999), pp.791-99.

${ }^{119} \mathrm{~S} / \mathrm{RES} / 1296$ (2000).
} 
This is not so reliable in new wars as the line between combatant and civilian is blurred, and civilians are often intentionally targeted in such wars. This underlines the importance of civilian casualties as a direct measure of conflict severity and indicator of risk to individuals. Finally, the human security paradigm suggests the need for measures of how a conflict impacts on sustainable living. Below we briefly examine four measures of conflict severity, the latter two suggested by the human security paradigm: battle deaths, civilian casualties, population displacement and state failure.

\subsection{Battle deaths}

The traditional metric of the severity of an armed conflict is the number killed in battle. The horror of WWI is routinely summed up by the scale of battle deaths which was somewhere between 13 and 16 million. ${ }^{120}$ Moreover, relative battle dead is commonly used to estimate the scale of victory and defeat in war. An oft cited example is the number of Coalition forces killed (only 240) in the 1991 Gulf War; there are no precise figures for Iraqi war dead with estimates varying from 20,000 to well in excess of $100,000 .{ }^{121}$

Significantly, battle dead is the core metric used to code interstate war in the largest quantitative database on war, the Correlates of War (COW) Project. Established in 1963, COW's aim is to collect and disseminate 'accurate and reliable quantitative data' on war in international relations. 1,000 must have died in battle for an interstate dispute to be coded as a war in the COW database. By this metric, the conflicts between Armenia and Azerbaijan (1992-95), Ethiopia and Eritrea (1998-2000), and India and Pakistan (1999) are all coded as inter-state wars. However, NATO's campaign against Yugoslavia over Kosovo (1999) is not coded as a war because with less than 1,000 military dead, it does not cross the 'battle-death threshold'. ${ }^{122} \mathrm{COW}$ is primarily concerned with militarized interstate disputes. It does gather data on intrastate conflicts and this dataset does include conflicts that do not cross the battle-death threshold. But all such cases are coded as having -999 battle deaths (this is the designation for cases that would not normally be included in quantitative analysis using COW datasets).

\subsection{Civilian casualties}

The severity of a war may also be measured by the numbers of civilians killed and injured. For instance, this metric is commonly applied in analysis of the toll of WWII. ${ }^{123}$ Indeed, given that this was a total war involving the mobilization of whole societies, it was to be expected and strategically appropriate that both the Allies and the Axis powers should wage war on civilians as well as each others forces. Hence, the slaughter of civilians was integral to the manner of

\footnotetext{
${ }^{120}$ William H. McNeil, The Pursuit of Power: Technology, Armed Force and Society since AD 1000, Chicago, 1982, at p.314.

${ }^{121}$ Stephen Biddle, Military Power: Explaining Victory and Defeat in Modern Battle, Princeton, 2004 ,at p.133.

${ }^{122}$ Faten Ghosn and Glenn Palmer, 'Associated Document for the Militarized Interstate Dispute Data, Version 3.0', Correlates of War 2 Project, 14 April 2003, available at http://www.correlatesofwar.org/

${ }^{123}$ Michael Sherry, The Rise of American Air Power, New Haven, 1987; A. C. Grayling, Among the Dead Cities, London, 2006.
} 
Japan's conquest of Asia and German's invasion of the Soviet Union. ${ }^{124}$ Equally, the Allied bombing campaigns against Germany and Japan were both directed against urban centres. Some 305,000 civilians were killed and 780,000 injured in the Combined Allied Bomber Offensive against Germany. ${ }^{125}$ US Army Air Force bombing of Japan (including the atomic bombing of Hiroshima and Nagasaki) killed some 330,000 civilians and injured 476,000. ${ }^{126}$

This metric of conflict severity is especially appropriate for internal armed conflicts, which often do not involve battle between recognized military forces and often do involve violence directed at civilian populations. For example, this applies to three internal armed conflicts which failed the COW battle-death threshold but led to loss of civilian life on truly massive scales: Cambodia 1975-78 (two million dead), Somalia 1990-91 (350,000 dead), and Rwanda 1994 (800,000 dead). ${ }^{127}$

This metric can be problematic in application, however. Data on civilian casualties in a specific conflict may vary considerably in substance and reliability. Often the parties (state and non-state) to a conflict are less interested in gathering accurate data on civilian casualties than in manipulating the data to support their own narrative of the conflict. In this sense, the very detailed studies by the US Army Air Force of the bombing campaigns in Europe and the Pacific were highly unusual. A similar effort was launched by the US Air Force following the 1991 Gulf War, but not the 1999 Kosovo War, the 2001-02 Afghanistan War, or the 2003 Iraq War. ${ }^{128}$

Data on civilian casualties in recent conflicts may be available from non-governmental organizations or other independent studies. But even here the figures may vary to a considerable degree. Hence an academic study published in The Lancet in October 2004 estimated that there were upward of 100,000 civilian deaths as a consequence of coalition military operations in Iraq between March 2003 and May 2004. ${ }^{129}$ In contrast, the Iraq Body Count (IBC) project put the number of civilians killed between March 2003 and January 2005 at 15,000 to 17,000. ${ }^{130}$ Underlying the variation in numbers were different methodologies. The Lancet study offered a projection of total dead based on a sample survey, whereas the IBC recorded civilian deaths that were confirmed by impartial sources (i.e., media, NGOs, hospitals, morgues, etc). ${ }^{131}$ Projecting the total number from a sample study could yield a more accurate estimate. But in the case of The Lancet study further concerns were raised about methodological flaws in the research design

\footnotetext{
124 John Dower, War without Mercy: Race and Power in the Pacific War, New York, 1986; Omar Bartov, Hitler's Army: Soldiers, Nazis, and the War in the Third Reich, Oxford, 1992.

125 The United States Strategic Bombing Survey (European War), Summary Report, 30 September 1945, p. 15, at http://www.anesi.com/ussbs02.htm\#tc

126 The United States Strategic Bombing Survey (Pacific War), Summary Report, 1 July 1946, p. 20, at http://www.anesi.com/ussbs01.htm\#thamotjc

${ }^{127}$ Milton Leitenberg, 'Deaths in Wars and Conflicts in the $20^{\text {th }}$ Century,' Cornell University Peace Studies Program, Occasional Paper No. 29, $3^{\text {rd }}$ edn, 2006, p. 8.

128 This is US Air Force's five volume Gulf War Air Power Survey published in 1993, at http://www.airforcehistory.hq.af.mil/Publications/Annotations/gwaps.htm

${ }^{129}$ Lee Roberts, Riyah Lafta, et al., 'Mortality Before and After the 2003 Invasion of Iraq: Cluster Sample Survey,' The Lancet (published online 29 October 2004), pp. 1-8, at http://image.thelancet.com/extras/04art10342web.pdf

${ }^{130}$ Civilian body count as of 4 January 2005, at http://www.iraqbodycount.net/

${ }^{131}$ IBC Press Release, 'IBC Response to the Lancet Study Estimating “100,000” Iraqi Deaths,' PR10, 7 November 2004, http://www.iraqbodycount.net/press
} 
and implementation. These concerns largely centred on the challenges for the survey team in having to rely on remote supervision of locally hired researchers to conduct the sample survey. ${ }^{132}$

Two further complications arise with estimating civilian casualties. First, that available figures may not be constructed so as to distinguish between combatant and civilian casualties. This was the case with The Lancet study noted above. This problem is indicative of the character of contemporary conflicts in which the line between combatant and civilian has become increasingly blurred. Second, estimates vary between direct and indirect casualties. Direct casualties are those killed and injured in fighting. Indirect casualties include those who are killed or suffer serious illness as a consequence of the affects of war, for example, from imprisonment, abuse, starvation, or even the destruction of critical infrastructure and services. Estimates of 'excess deaths', such as the The Lancet study include the latter, which would have contributed to inflation in the casualty figures in that study. In contrast, the IBC record direct deaths only. However, in some cases, full appreciation of the severity of the conflict is impossible without including indirect casualties. For example, of the 2 million civilians that perished in Cambodia between 1975 and 1978, only 80,000-100,000 were directly killed; the rest died of starvation and disease because of the policies of the repressive Pol Pot regime. ${ }^{133}$

In sum, civilian casualties generally provide a truer estimate of the severity of armed conflict. This is increasingly the case with contemporary conflict, which often involves mass violence directed against civilians. However, compiling reliable data, especially comparative data, on civilian casualties involves methodological choices and challenges.

\subsection{Population displacement and state failure}

The human security paradigm suggests that the severity of armed conflict needs to be assessed in the context of broader social impacts, especially for sustainable living. This perspective points to two possible metrics. First, is the number of people displaced from their homes, including both refugees and internally displaced persons (IDPs). In UNSC resolutions 688 (1991), 841 (1993) and 1199 (1998) - on the humanitarian crises in Northern Iraq, Haiti, and Kosovo respectively refugee flows were recognized as constituting a threat to international peace and security. ${ }^{134}$ Moreover, two of these cases triggered an international armed intervention despite the relatively low number of civilian deaths prior to intervention: 3,000 in Haiti (between 1991 and 1994) and only 500 civilians in Kosovo. Reliable comparative data on refugees and IDPs are usually available from the UNCHR.

The second metric is state failure. Where state failure is especially chronic, leading to the collapse of infrastructure and basic services (including law and order), life for communities may become unsustainable. A number of non-governmental organisations track state failure. The most authoritative assessment is provided by the Failed State Index created by the Fund for

132 Neil Munro and Carl M. Cannon, 'Data Bomb,' The National Journal, 4 January 2008, at http://news.nationaljournal.com/articles/databomb/index.htm

${ }^{133}$ Leitenberg, p. 5.

${ }^{134}$ Guy S. Goodwin-Gill and Jane McAdam, The Refugee in International Law, Oxford University Press, 2007, at pp.5-6. 
Peace, which applies 12 measures of state weakness grouped in social, economic and political indicators: these include demographic pressures, mass population movement and displacement, uneven economic development, sharp economic decline, deterioration of public services, widespread violation of human rights, and intervention by external states and other actors. ${ }^{135} \mathrm{We}$ are especially interested in the impact of state failure on sustainable living, and this may be assessed by looking at statistics for child mortality, food poverty, sanitation, access to clean drinking water, and so forth. Of course, state failure is a causal factor in internal armed conflict, but equally armed conflict can cause state failure. ${ }^{136}$ Indeed, there is a strong correlation between the two: states that have experienced internal armed conflict are statistically far more likely to suffer cycles of spiralling institutional and social failure and repeated conflict. ${ }^{137}$ It should be noted that in many cases, mass population displacement and state failure will coexist; the former will be an indicator, and may be a further contributor, of the latter.

If we consider conflict severity in four cases - the Democratic Republic of the Congo (DRC), Chad, Somalia and Sudan - the importance of these two metrics becomes evident. For each of these conflicts we compare metrics for a particular conflict year for which we have been able to obtain comparative data.

Table 1: Conflict severity in four cases

\begin{tabular}{|c|c|c|c|c|}
\hline & DRC (2000) & Chad (2000) & Somalia (2007) & Sudan (2007) \\
\hline Killed in conflict ${ }^{138}$ & 36,250 & 100 & 547 & 2718 \\
\hline $\begin{array}{l}\text { Displaced } \\
\text { population } * 139\end{array}$ & 317,000 & 54,000 & $85-115,000$ & $500-625,000$ \\
\hline Under 5 mortality ${ }^{140}$ & $17.9 \%$ & $20.5 \%$ & $14.2 \%$ & $10.9 \%$ \\
\hline Children & $31.1 \%$ & $28.1 \%$ & $35.6 \%$ & $31 \%$ \\
\hline
\end{tabular}

underweight $* * 141$

* Figures for refugees and IDPs, except for Chad where the figure is for refugees only.

** Figures for child malnutrition are for DRC in 2001, Chad in 2000, and Somalia and Sudan in 2006.

The first thing that is immediately striking is that the fatality numbers for these conflicts are low with the exception of DRC. Accurate casualty data are especially difficult to obtain. We are using the Armed Conflict Dataset compiled by the International Peace Research Institute (PRIO) in Oslo. These figures are for both battle deaths and civilians killed in conflict. PRIO data offers

\footnotetext{
$135 \mathrm{http}: / /$ www.fundforpeace.org/web/index.php?option=com_content\&task=view\&id=391\&Itemid=549

136 Robert Rotberg (ed), When States Fail: Causes and Consequences, Princeton, 2004; Robert Bates, 'State Failure,' Annual Review of Political Science 11 (2008), at pp.1-11.

${ }^{137}$ World Bank, Breaking the Conflict Trap: Civil War and Development Policy, Oxford, 2003; Paul Collier, The Bottom Billion, Oxford, 2007.

${ }^{138}$ Bethany Lacina and Gabriel Uriarte, “The PRIO Battle Deaths Dataset, 1994-2008," Version 3.0, September 2009, pp. 118, 171, 484, 515, at http://www.prio.no/cscw/Datasets/Armed-Conflict/Battl-Death/. Note, notwithstanding the name of this dataset, the data includes combatants and civilians killed in conflict.

${ }^{139}$ UNHCR Statistical Population Database, at http://www.unhcr.org/statistics/populationdatabase; Somalia and Sudan figures also includes data from OCHA Regional Office for Central and East Africa, Displaced Population Reports, at http://ochaonline.un.org/rocea/

${ }^{140}$ UN Millennium Development Goals Indicators Database at http://mdgs.un.org/unsd/mdg/Data.aspx

${ }^{141}$ UN Millennium Development Goals Indicators Database at http://mdgs.un.org/unsd/mdg/Data.aspx
} 
high and low estimates; the figures above are the high estimates. The war in DRC from 19982003 drew in so many neighbouring states and was waged at such a scale as to lead the US Secretary of State to describe it as "Africa's World War" before the UN Security Council in $2000 .{ }^{142}$ In 2000 alone, over 36,000 people were killed in the conflict and almost ten times that number displaced from their homes. As might be expected in a country wracked by war, DRC was and remains a failed state. The Failed State Index began ranking failed states in 2005, and at this time DRC ranked second after the Côte d'Ivoire. ${ }^{143}$ The impact on sustainable living is evident with almost one in five children dying before their fifth birthday in 2000, and almost one third of children moderately to seriously underweight in 2001.

Compare this with the civil war in Northern Chad from 1998-2002, waged between government forces and those of the Movement for Justice and Democracy in Chad. In 2000 only 100 were killed in conflict. ${ }^{144}$ However, the conflict created sufficient insecurity to drive over 50,000 to flee the country; we do not have figures for IDPs but it would be reasonable to assume that far greater numbers of civilians were displaced within the country. The impact on sustainable living from this conflict is suggested by child mortality and malnutrition rates that are comparable with those in DRC at the time. Looking at more recent armed conflicts, again we find that the numbers of combatants and civilians killed provides a poor indicator of the true impact of conflict on civilian life. Again, the number of those displaced is hugely disproportionate to the number of those directly killed in conflict. In Somalia in 2007, 547 died as a result of fighting but 200 times as many people fled their homes. In Sudan, the difference is even more pronounced with 2,718 killed and in excess of 600,000 displaced. Moreover, conflict had caused both states to collapse: Somalia was ranked third and Sudan was ranked first on the Failed State Index in 2007. Child mortality in both states was better than DRC and Chad in 2000 (possibly due to more effective humanitarian aid), whilst child malnutrition was as bad in Sudan and worse in Somalia in 2007. In sum, as Chad in 2000, and Sudan and Somalia in 2007 demonstrate, even when civilian deaths are added to battle deaths, the combined figure can still produce an inadequate indicator of conflict severity, especially with regard to the impact on sustainable living.

In sum, the above discussion suggests four metrics that may be applied in determining the severity of an armed conflict and the accordant threat to civilians: (i) battle deaths, (ii) civilian casualties; (iii) population displacement; and (iv) state failure. The changing character of war, with the blurring of military and civilian actors and spaces, and rise of civilian targeting, suggests that civilian casualties will be a more significant metric than battle deaths in measuring war severity. We would also highlight the human security paradigm, which points to the impact of armed conflict on sustainable living of individuals and communities.

\section{ASSESSING CONFLICT SEVERITY AND SERIOUS THREATS}

\footnotetext{
${ }^{142}$ U.S. General Account Office (GAO), UN Peacekeeping, GAO-01-917 (Washington, D.C., USGAO, September 2001), p. 52.

$143 \mathrm{http} / /$ www.fundforpeace.org/web/index.php?option=com_content\&task=view\&id=103\&Itemid=325

144 This number is low even for this conflict. 553 were killed in conflict in Chad in 1999, and 418 were killed in 2001. Lacina and Uriarte, "The PRIO Battle Deaths Dataset," p. 118.
} 
It follows from the discussion in section 3 that an assessment of the severity of an armed conflict - in terms of intensity of the indiscriminate violence - is at the core of the analysis on the 'true meaning and effect of article $15^{, 145}$ in both the French courts and the courts for England and Wales. The jurisprudence from these courts on Article 15(c) has so far dealt exclusively with direct threats in terms of exposure to violence existing as a result of an armed conflict, including criminal acts (which according to the UK AIT in KH (Iraq) are not caught by Article 15(c) but according to the most recent GS (Afghanistan) case are - see below; the French courts too agree that criminal acts are caught by Article 15(c)). Yet, as we have argue above, indirect threats in armed conflict exist too, such as rapid and chronic collapse of basic infrastructure and social order - and create very serious threats to individuals, especially during the early part of an armed conflict when no social coping mechanisms exist.

The Court of Appeal in $Q D \& A H$ (Iraq) realised the importance of seeking to identify the 'kind or degree of risk to individuals ... required to bring a situation of armed conflict within the purview of article 15(c)'. ${ }^{146}$ This had been an issue going beyond what the ECJ had been called to rule upon, and so the Court of Appeal referred back to the KH (Iraq) case, as decided by the AIT. The Court of Appeal also found that it was not necessary to show a 'consistent pattern' of harm arising from indiscriminate violence (as expressed in $A A$ (Zimbabwe)) because 'The risk of random injury or death which indiscriminate violence carries is the converse of consistency'. ${ }^{147}$ Instead, the Court of Appeal found that an applicant would have to show that incidents of indiscriminate violence 'were happening of a wide scale and in such a way as to be of sufficient severity to pose a real risk of serious harm...to civilians generally'. ${ }^{148}$ The Court of Appeal further held that it is not necessary to satisfy an additional test of 'exceptionality' because when the ECJ used this language in Elgafaji (paras. 37-38), they simply intended to stress the intensity of indiscriminate violence. Thus, the Court of Appeal concluded that the focus of enquiry is simply on the key test: whether the degree of indiscriminate violence characterising the armed conflict has reached 'such a high level' that the Article 15(c) test is met solely by a civilian being present in that territory.

We elaborated above four metrics that may be applied in assessing the severity of an armed conflict. The traditional metric is battle casualties. However, given the character of new wars, we have argued (in section 4.) that civilian casualties generally provide a truer estimate of the severity of armed conflict. Furthermore, the human security paradigm suggests that the severity of armed conflict needs to be assessed in the context of broader social impacts, especially for sustainable living. This perspective points to two possible metrics. First, is the number of people displaced from their homes, including both refugees and internally displaced persons (IDPs). Second, is chronic state failure leading to the collapse of infrastructure and basic services (including law and order), and making life for communities unsustainable.

Indeed, it may be argued that the human security is most 'appropriate as a guide for applying Article 15(c), given that the provision's interpretation of Article 15(c) is to be driven by

\footnotetext{
${ }^{145}$ Sedley LJ, $Q D \& A H$ (Iraq), para.5.

${ }^{146} Q D \& A H$ (Iraq), para.32.

${ }^{147} Q D \& A H$ (Iraq), para.32.

${ }^{148} Q D \& A H$ (Iraq), para.33.
} 
preambular objectives such as Recital (10), which stresses human dignity'. ${ }^{149}$ It is also consistent with the AIT's statement in KH (Iraq) that "life or person" is to be given a broad meaning, we would accept that the phrase must encompass the means for a person's survival'. ${ }^{150}$ It is further consistent with the UNHCR submission as an Intervener in $Q D \& A H$ (Iraq) that all forms of violence should be taken into account, i.e., violence emanating both directly from the conflict itself, and from other sources such as opportunistic criminals taking advantage of the breakdown of law and order. ${ }^{151}$

We would further argue that for Article 15(c) to be meaningful, its scope must offer something going beyond that of Article 15(b) (i.e., Article 3 ECHR). This is especially true in the light of the statement of the European Court of Human Rights in $N A v$. United Kingdom, that 'only in the most extreme cases of general violence' would forced return entail responsibility under Article 3, for example, where 'the general situation makes it more likely that the authorities will systematically ill-treat' the members of a particular group. ${ }^{152}$ And in Salah Sheekh v. The Netherlands, whilst the Strasbourg Court recognised 'the acute pertinence of socio-economic and humanitarian considerations to the issue of forced returns of rejected asylum seekers to a particular part of their country of origin', it found that 'such considerations do not necessarily have a bearing, and certainly not a decisive one' on the assessment of real risk under Article $3 .{ }^{153}$

Here it is important to recall, as we discussed earlier, that both the French Conseil d'Etat, in $M$. Baskarathas, and the AIT, in $A M \& A M$ (Somalia), have acknowledged that forced (or mass) displacement of civilians constitutes evidence of the existence of severe indiscriminate violence in a situation of armed conflict.

In GS (Article 15(c): indiscriminate violence) Afghanistan $C G,{ }^{154}$ a case recently decided by the AIT, the Tribunal considered the applicability of the four metrics we have elaborated herein and which, at the time, were presented by Theo Farrell in a written submission to the Tribunal. The current phase of armed conflict in Afghanistan has been on-going since 2001. Professor Farrell noted that, as wars go, this conflict has killed relatively few combatants. The North Atlantic Treaty Organisation (NATO) lost just over 1,050 personnel killed in action (KIA) from October 2001 to September 2009. ${ }^{155}$ There is no reliable data on battle deaths for the Afghan government security forces or for the anti-government insurgent forces. Reports suggest that the antigovernment (mostly Taliban) forces have suffered many thousand dead, especially in intense fighting in Southern and Eastern Afghanistan in 2006-2007. ${ }^{156}$ At this level of intensity, the

\footnotetext{
149 Symes, 'Skeleton Argument' in GS (Afghanistan), at p.9 (on file with the author). Human dignity is further protected in Article 1 of the Charter of Fundamental Rights of the European Union: 'Human dignity is inviolable. It must be respected and protected' (OJ, 18.12.2000, C 364/1-22), itself based on the preamble to the 1948 Universal Declaration of Human Rights.

${ }^{150} \mathrm{KH}(\operatorname{Iraq})$, para.106.

${ }^{151}$ UNHCR Submission in $Q D$ and $A H$ (Iraq), Annexure 1.

${ }^{152}$ NA v United Kingdom, Application No. 25904/07, 17 July 2008, paras.115-117.

${ }^{153}$ Salah Sheekh v. The Netherlands, Application No.1948/04, 11 January 2007, para.141. The considerations had been advanced by the UNHCR.

${ }^{154}$ GS (Article 15(c): indiscriminate violence) Afghanistan CG [2009] UKAIT 00044, 19 October 2009.

155 The Brookings Institution, 'Afghanistan Index: Tracking Variables of Reconstruction and Security in Post-9/11 Afghanistan, 23 September 2008, p. 6, at http://www.brookings.edu/afghanistanindex

${ }^{156}$ See, for example, Richard Norton-Taylor, '600 Taliban Killed in Bloodiest Month for 5 Years,' The Guardian, 26 July 2006, at http://www.guardian.co.uk/world/2006/jul/26/afghanistan.afghanistantimeline
} 
armed conflict in Afghanistan exceeds the COW battle-death threshold, but the number is still low. The number of civilians killed by the armed conflict also remains mercifully low; from mid 2006 to late 2009 , around 5,900 civilians were directly killed by the war. ${ }^{157}$

Judging by the numbers of war dead, Afghanistan does not appear to be that severe, and one might be inclined to infer from this that the threat to individuals is reasonably low. However, when the two additional metrics are applied a different picture emerges. The conflict in Afghanistan has resulted in massive displacement of the population. Throughout 2006 and 2007, Afghanistan was the leading country of origin for refugees, producing 3.1 million refugees or $27 \%$ of the global refugee population. This amounts to almost $10 \%$ of the population of Afghanistan. Afghans sought refuge in 72 countries worldwide, though $96 \%$ of Afghan refugees relocated to Pakistan or Iran. ${ }^{158}$ The UNCHR also reported a "significant increase" in the IDP population in Afghanistan in 2007, though accurate figures for IDPs are more difficult to come by. ${ }^{159}$

Almost continual war since the Soviet invasion of 1979 has shattered the Afghanistan state and civil society. Thirty years on, Afghanistan clearly is a failed state. It is ranked seventh on the Failed State Index for 2009. Another ranking by the Brookings Institution places Afghanistan second in its 2008 'Index of State Weakness in the Developing World.' ${ }^{160}$ The impact on sustainable living is evident, with only 1 in 5 Afghans having access to safe drinking water and only $12 \%$ having access to adequate sanitation in 2008. Infant mortality in Afghanistan is $13 \%$ and $20 \%$ for under-fives. In 2007, $45 \%$ of Afghans experience food poverty (i.e., a daily food intake below the world minimum standard of 2,100 calories). ${ }^{161}$ Thus, in terms of population displacement and state failure, Afghanistan is a most severe armed conflict that has made sustainable living impossible for millions of Afghans who have fled their homes. Accordingly, Professor Farrell argued that whilst the direct threat to civilians from being killed may be low in this armed conflict, the indirect threat associated from chronic state failure is considerable.

Hence, the AIT was faced with having to decide whether to accept indirect - not just direct consequences of indiscriminate violence when assessing what forms of harm are faced by returning civilians and whether 'such high level' is met. It considered this question to fall under the 'causal nexus' between 'the serious and individual threat' and 'the indiscriminate violence'. At one end of the spectrum, one would have a solution whereby all the forms and consequences of violence in a country should be deemed relevant to Article 15(c). At the other end, one would have a most restrictive interpretation of 'indiscriminate violence' (such as in KH (Iraq)), as put forward by Counsel for the respondent: 'It is only where the violence which is targeted against the military or police is pursued by means which are so excessive and disproportionate that civilians are as likely as not to be affected (that is, where the perpetrator of the violence simply

\footnotetext{
${ }^{157}$ Brookings, 'Afghanistan Index,' p. 4.

${ }^{158}$ UNHCR, 2007 Global Trends: Refugees, Asylum-Seekers, Returnees, Internally Displaced and Stateless Persons, June 2008, p. 8, at http://www.unhcr.org/statistics.html

${ }^{159}$ UNHCR, 2007 Global Trends, p. 18.

${ }^{160}$ Susan E. Rice and Stewart Patrick, Index of State Weakness in the Developing World (Washington, D.C.: Brookings Institution, 2008), p. 5, at http://www.brookings.edu/reports/2008/02 weak states index.aspx

${ }^{161}$ Brookings, 'Afghanistan Index,' pp. 25-26.
} 
does not care who is affected by the attack) that such violence may truly be said to be "indiscriminate",. ${ }^{162}$ The Tribunal found this to be 'a question of fact in each case'. ${ }^{163}$

Looking at the situation in Afghanistan, the AIT noted that 'a significant proportion of the population does not have sufficient food and significant numbers have died of starvation'. Yet, and contrary to counsel's argument for the appellant and UNHCR view, it concluded that 'it cannot be said that such a general situation has come about "by reason of indiscriminate violence in situations of international or internal armed conflict". ... The food supply problem cannot be shown to be connected otherwise than very remotely to indiscriminate violence, even if it more closely connected to armed conflict'. ${ }^{164}$ Hence, Recital (10) [i.e., seeking to ensure full respect for human dignity] is only 'an aspiration', and UNHCR view 'is not persuasive of the interpretation of the Qualification Directive'. ${ }^{165}$ Accordingly, of the four metrics presented by Farrell to the AIT, the Tribunal chose to concentrate on civilian casualties because it provides 'a truer estimate of the severity of an armed conflict than battle casualties ${ }^{166}$ and because the other two (mass population displacement and state failure) 'may provide reinforcing evidence when looking at the severity of an armed conflict, [but] they are not necessarily independent tests of conflict severity'. ${ }^{167}$ The AIT concluded that 'the numbers of casualties involved would not elevate the risk sufficiently to bring the general situation within Article 15(c) ${ }^{\prime} .{ }^{168}$ In this case, the AIT noted that 'the one thing which struck us particularly was Professor Farrell's assertion that the number of civilian fatalities directly caused by both sides to the conflict in Afghanistan (including those assassinated by the Taliban/al Qaeda) was low in comparison with conflicts of a similar size elsewhere. ${ }^{169}$

Moving on to the more 'finessed' test expressed in paragraph 39 of the Elgafaji ruling, the AIT discussed briefly the novel question of 'enhanced risk to particular categories of individuals', and agreed that examples of such groups could (depending on the facts of each case) be 'collaborators', for example, or a 'teacher' or a 'disabled person', but found that the applicant did not fall into any such enhanced risk category in this case. The AIT further observed that any such person may in fact be entitled to refugee status. This is an issue that finds numerous illustrations in the French case law, as discussed above, and which has led, at least in France, to subsidiary protection status being very much subsidiary to refugee status.

\section{CONCLUSION}

\footnotetext{
${ }^{162}$ Robert Palmer, 'Skeleton Argument' in AIT GS (Afghanistan), p.16.

${ }^{163}$ GS (Article 15(c): indiscriminate violence) Afghanistan CG [2009] UKAIT 00044, para.67.

${ }^{164}$ GS (Afghanistan), para.69.

${ }^{165}$ GS (Afghanistan), para.71.

${ }^{166}$ GS (Afghanistan), para.82.

${ }^{167}$ GS (Afghanistan), para.83. We fear the AIT may have misunderstood Professor Farrell's point, which was that mass displacement and state failure may not provide tests of conflict severity that are independent of one another in those conflicts where mass displacement has contributed to state failure. However, mass displacement and state failure do provide measures of conflict severity that are independent of battle deaths and civilian casualties, as is argued in this article and indeed as Professor Farrell attempted to argue in his submission to the AIT.

${ }^{168}$ GS (Afghanistan), para.125 - as per paragraph 35 of the Elgafaji ruling.

${ }^{169}$ GS (Afghanistan), para. 117.
} 
The case law discussed in this article shows that at present, and despite Article 15(c), there exist normative gaps (perhaps less in the law itself than in the way the law is being interpreted) which means that people who flee an armed conflict are not finding protection in the UK or France, even though they cannot return because their country has become uninhabitable owing to the conflict. In both English (including Wales) and French jurisprudence on Article 15(c), the key test applied by the courts is that elaborated by the ECJ in Elgafaji (paragraph 35), i.e., the degree of indiscriminate violence characterising the armed conflict, which should be of such a high level that substantial grounds exist for believing that a civilian, if returned to the relevant country/region, would, solely on account of his/her presence there, face a real risk of being subject to a serious threat of real harm. However, in applying this test, the case-law from France and England shows some important differences. For instance, in the English courts, Article 15(c) may not be read in the light of IHL, whereas it may in the French courts. The English courts specify that Article 15(c) is concerned with serious threats of real harm and does not require a consistent pattern of risk. The French courts approach Article 15(c) slightly differently, recognising that 'generalised violence' is inherent to a situation of armed conflict and in fact characterises it.

The English courts have been struggling with the question of how to assess the severity of armed conflict and associated seriousness of risk of real harm, in applying Article 15(c). As noted above, the French courts have yet to consider this question; instead they have applied the grounds for protection specified under the Refugee Convention in considering cases for subsidiary protection. In this article, we have elaborated four metrics for assessing conflict severity: battle casualties, civilian casualties, population displacement, and state failure. From an assessment of conflict severity, one may infer seriousness of risk to individuals from indiscriminate violence. We have argued that the character of armed conflict has changed in such a manner has to increase the exposure of civilians to the effects of war. This would give added weigh to the value of civilian casualties over battle casualties in assessing conflict severity. We also noted the rise of the human security paradigm, which highlights the indirect threats from armed conflict to sustainable life by communities. Accordingly, we proposed population displacement and chronic state failure as two key metrics in assessing the impact of armed conflict on sustainable living. All four metrics were recently considered by the AIT in the GS (Afghanistan) case. The AIT accepted the argument that civilian casualties provided a more useful metric than battle casualties in considering a case involving the ongoing armed conflict in Afghanistan. However, the Tribunal was not inclined to recognise population displacement and state failure as useful metrics in this case, because the causal link between armed conflict and these phenomena were deemed too complex to unpack. As it happens, the AIT had previously acknowledged in $A M \& A M$ (Somalia) mass displacement as indicative of conflict severity, as has the French Conseil d'Etat in M. Baskarathas. We recognise that demonstrating the causal links between armed conflict and mass population displacement and chronic state failure represents a significant empirical challenge. But there are growing bodies of scholarship that demonstrate in empirical detail what is obvious as a general observation: armed conflict destabilises states, and populations flee areas of armed conflict because life becomes unsustainable in such areas. ${ }^{170}$

\footnotetext{
${ }^{170}$ World Bank, Breaking the Conflict Trap: Civil War and Development Policy, 2003; Robert H. Bates, 'State Failure', Annual Review of Political Science 11 (2008); Paul Collier, Bottom Billion, Oxford University Press, 2007; Robert I. Rotberg (ed.), When States Fail, Princeton University Press, 2003.
} 
As a final observation, we would note recent development in human rights jurisprudence which gives added normative weigh to consideration of indirect threats in applying Article 15(c). The European Court of Human Rights in NA v United Kingdom recognised, in paragraph 115, 'the possibility that a general situation of violence in a country of destination [may] be of sufficient level of intensity as to entail' protection under Article $3 \mathrm{ECHR}$, but only in the most extreme cases of general violence. When assessing 'real risk', the Strasbourg Court found socioeconomic and humanitarian considerations, although relevant, not to have a decisive bearing on the assessment. The Dutch Council of State, on 25 May 2009 in the Elgafaji case, re-affirmed that Article 3 ECHR includes the exceptional circumstances covered by Article 15(c), as laid down in paragraph 43 of the ECJ's ruling in this case, which it claimed corresponds to paragraph 115 of the European Court of Human Rights in NAv United Kingdom. So, the usefulness of Article 15(c), as currently interpreted by the national courts, remains in question. As McAdam noted a 'deep-seated fear that whole populations will flee on the basis of generalized violence if subsidiary protection status does not require individual harm to be demonstrated ${ }^{171}$ seems to have tainted the whole system. Hence, an argument may also be made here for the phrase 'indiscriminate violence' in Article 15(c) to include indirect threats on the basis of respect for human dignity. In this regard, the human security paradigm could prove to be a valuable guide for the courts.

\footnotetext{
${ }^{171}$ McAdam, Complementary Protection, p.74
} 